\title{
Infrastructure system planning for affordable housing for workers in Hanoi, Vietnam
}

\author{
Hoang Quyen Dang ${ }^{1, *}$ \\ ${ }^{1}$ Department of Architecture, Ho Chi Minh City University of Architecture, 196 Pasteur Street, \\ District 3, Ho Chi Minh City, Vietnam
}

\begin{abstract}
Established industrial zones have contributed to the development of economy, the creation of jobs, and an increase in the income for workers. However, their living condition has yet been recognized with full attention. Affordable housing projects for laborers have been built in some areas, but the infrastructure system has not been carried out for a long time, leading to negative impacts on the lives of workers. Therefore, it is necessary to study the planning process of infrastructure system for social housing. The research reveals a few methods to establish infrastructure system consistently, such as planning solutions, investing process, and policy innovation. Besides, the study proposes the solution for assessment of infrastructure quality in affordable housing for workers. The research applied the assessing system to evaluate two social housing areas in Hanoi, Vietnam. Results of this study may become a reference for planning infrastructure system for workers' housing. Ensuring the lives of employees is the foundation of social security that helps improve the efficiency of labor and develop national economy.
\end{abstract}

\section{Introduction}

Based on the Vietnamese Construction Law in 2014, infrastructure system includes 'technical infrastructure' and 'social infrastructure'. The term 'technical infrastructure' means public transport, power supply, water supply, drainage system, telecommunications, and waste collection. The term 'social infrastructure' relates to cultural and educational institutions, health facilities, sport centers, financial or retail areas, parks, playgrounds, and other public areas [1]. Practice shows that the establishment of the affordable housing for workers and infrastructure system related to the fill rate of industrial parks. Although infrastructure planning regulations are mentioned in Vietnamese law, it is not specific enough to apply for different residential areas. Studies have shown that infrastructure investment reveals some difficulties such as large capital outlays, low profit and long payback period. It leads to the lack of essential infrastructure projects for the lives of employees. The objectives of the current study are finding out real needs of people living in affordable housing areas and proposing methods to enhance efficiency in developing the infrastructure system in workers' housing projects.

\footnotetext{
* Corresponding author: quyen.danghoang@uah.edu.vn
} 


\section{Literature review}

The study mentions infrastructure system in workers' housing in both developed countries and a newly industrialized country including Canada, France, Japan and South Korea. Besides, some countries have contexts similar to Vietnam such as Malaysia and Thailand will be referred.

\subsection{In developed and newly industrialized countries}

\section{Canada}

All affordable housing projects in Canada are managed by an agency from the government named Social Housing Services Corporation (SHSC) [2]. SHSC is responsible for providing housing for the people with low-income. Developing housing is carried out to establish infrastructure system by the government. Until now, Canada is one of a few countries that have social housing resources with completed infrastructure system in the world [3].

\section{France}

From 1953, the government issued policies that every company with more than 10 workers must spend $1 \%$ of its income tax to contribute to the fund for building affordable housing for employees and infrastructure system. By 1955, France had up to 3.9 million units of affordable housing for rent, accounting for $41 \%$ of housing in all over the country. So far, France provided housing rather completely for low-income people with full system of infrastructure [3].

\section{Japan}

After the World War II, policy-makers cooperated with IP investors on developing comprehensive infrastructure system with each housing project for workers, such as social infrastructure, and entertainment areas. In Osadano IP (Fukuchiyama, Kyoto), local authority spent around 60 hectares in 400 hectares of IP on affordable housing project for laborers. In particular, the authority worked in collaboration with private companies to establish kindergartens, primary schools, secondary schools and other buildings [4].

\section{South Korea}

The government provided housing for industrial workers. The Korea National Housing Corporation (KNHC) provided three types of apartments: single-family, row-houses and apartment housing. The KNHC had built apartments for workers working in Saemul Undong Industry with facilities such as health centers, hobby clubs. They suggested workers to join in the nature preservation campaign and helping hands farmers [5].

\subsection{In developing countries}

\section{Malaysia}

All standards of affordable housing are managed by the Ministry of Housing and Local Government and the National Housing Department [6]. Based on the Seventh Malaysia Plan (1996-2000) and Eight Malaysia Plan (2001-2005), Malaysian government is committed that all their citizens will be provided adequate, affordable and quality housing [7]. In 1990, Malaysia issued "Workers' Minimum Standards of Housing and Amenities" [8]. It includes the regulations with regard to social infrastructure for workers' housing, such as schools, hospitals, community hall, sports and other recreational facilities. In the first period of formation, 21,561 units were built associated with 259 kindergartens, and 69 community halls [9]. The government encouraged companies to establish housing and infrastructure system for workers. In the developing period, local authorities and companies provide many 
services, other recreational facilities to increase life quality and to meet the increasing demands of laborers.

\section{Thailand}

Since 1986, Thailand has had outstanding economic growth. It helped transform this country from an agricultural country into an industrial one [10]. Some private companies built workers' housing for their labors. The projects are near their factories in order to ensure workers can arrive on time [5].

Workers' housing does not belong to urban areas from the view of administration. As the result, at that time affordable housing for workers lack essential infrastructure [10]. In 1982, National Housing Authority (NHA) built 4 blocks with 756 rental units in the Navanakorn Industrial Estate. Nearly 30 factories in this industrial zone rent 400 units from the NHA for their labors [5]. There are not any infrastructure facilities were mentioned.

\subsection{In Vietnam}

In Vietnam, a workers' housing study mentioned that there are about 2.6 million workers working in industrial zones, but only $20 \%$ of them have stable housing, the rest has to rent house with poor living conditions [11]. Labor in the industrial sector in Vietnam now has a high proportion of young people and the percentage of single workers accounts for $60-70 \%$. The survey by the Institute of Labor shows that the average salary of workers now is nearly VND 4,000,000/person/month (around USD 176).

Although it has improved about $10 \%$ compared to the year 2014, this salary has only met $78-83 \%$ of the basic expenditure needs of workers. The price of renting is from VND 300,000 to VND 400,000/person/month (about USD13 to USD 18/person/month). Meanwhile, most of the apartments are very narrow and there are no social infrastructure facilities such as kindergartens, schools, clinics, recreation centers, sports facilities, libraries [12].

According to the National strategy on Housing development through 2020 with a vision toward 2030 , there are about $70 \%$ of workers in industrial zones wishing to rent or buy houses [13]. Up to August 2015, 83 workers' housing projects were built with 28,000 apartments and total capital is VND 6.6 billion (approximately USD 291,100) [11].

Some affordable housing projects have the social infrastructure system with schools, cultural and sport centers. However, in general, their quantity is not enough to meet the needs of workers. A few buildings were constructed for laborers, yet the service price is too expensive to use for most of them.

A survey from Vietnam general confederation of labor illustrated that there were more than 150 local cultural centers all over the country. The lack of kindergartens and primary schools for children of employees in the industrial parks is one of the most important issues. Many employees have small children, yet the number of kindergartens has not been enough. The regulations of planning affordable housing projects have provisions in terms of the educational institutes [14]. However, it is the fact that requirement of construction license is rather complicated and it takes a lot of time to have them. Another reason is the lack of capital for social infrastructure investment.

Some studies in terms of social housing and workers' housing have been carried out in Vietnam. However, there are not any specific studies with regards to infrastructure system in housing for workers - an important issue that directly affects the worker's life. This research fills the gap in this subject with social condition in Vietnam. To evaluate the quality of infrastructure system in affordable housing projects, this research used a few procedures to measure housing quality by assessing indicators $[15,16]$. 


\section{Materials and methods}

\subsection{Case studies}

The research was carried out in Hanoi - the capital and the country's second largest city by population. According to a statistic from Hanoi Department of Construction, there are 10 industrial parks in operation with a total area of 1,700 hectares, creating more than 114,000 jobs for workers. However, until now we just have 04 affordable housing projects, including North Thang Long IP affordable housing, Phu Nghia IP affordable housing, affordable housing for workers of Meiko Electronics Vietnam Company and Young Fast Otoelectronics Company (Thach That - Quoc Oai IP). In these projects, only the affordable housing in North Thang Long IP has fully-equipped social infrastructure system with kindergartens, supermarkets, and clinics, cultural and sport centers. The rest lacks essential social infrastructure. For instance, in Phu Nghia affordable housing, distance from the project location to the nearest market is more than 2 kilometers.

Two affordable housing areas are chosen to become the case studies including North Thang Long IP affordable housing (Total area: 199,447 square meters; Fill rate of IP: 100\%; Formation time of IP: 1997) and Phu Nghia IP affordable housing (Total area: 39,960 square meters; Fill rate of IP: 30\%. Formation time of IP: 2008) (See Figure 1).

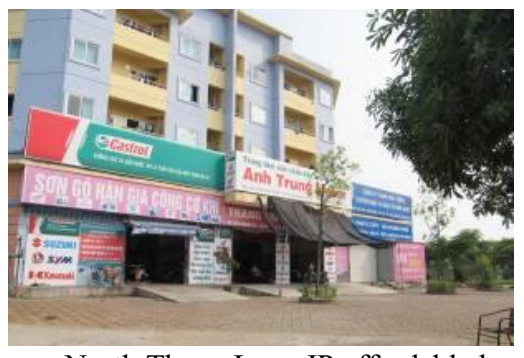

North Thang Long IP affordable housing

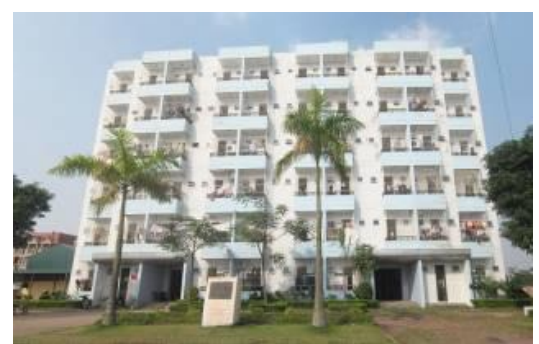

Phu Nghia IP affordable housing

Fig. 1. Social infrastructure system in affordable housing projects.

\subsection{Method of evaluating the quality of infrastructure system in affordable housing projects}

Step 1: Proposing a system of indicators to measure infrastructure quality with component factors.

There should be a system of indicators for evaluating the quality of infrastructure system. It will help both investors and laborers determine the real value of infrastructure quality in affordable housing projects. Each indicator should have some component factors. They will help evaluate more clearly the quality of criterion.

Step 2: Determine weighting values and evaluated points of indicators

The survey was carried out on 150 workers living in affordable housing areas of North Thang Long IP and Phu Nghia IP. The questionnaire has two main parts. The first one is assessing the importance of each indicator in general (in 03 levels: Very important, Important, and Not important). By using the percentage of evaluation report, the weighting values of indicators are established. The second part of the questionnaire is to determine the evaluated points of criterion in their affordable housing areas based on the features of components factors (evaluated points are from 0 to 100 points).

Step 3: Assessing quality of infrastructure system based on weighting values

Indicator point $\mathrm{i}=$ Evaluated point $\mathrm{i} x$ Weighting value $\mathrm{i}(\%)$ 
Total point $=\sum_{i=1}^{n}$ Indicator point $\mathrm{i}$

Step 4: Determine level of infrastructure system quality

Levels of infrastructure system quality are evaluated based on the stage of developing affordable housing project.

\section{Results}

\subsection{Developing infrastructure system in affordable housing projects closely related to the formation and development of industrial parks}

Based on the formation of industrial parks, it is proposed to divide the formation and development period of infrastructure system in affordable housing projects into 3 stages (See Figure 2):

- Stage I: Planning: the process concerned with the design, the development and use of land;

- Stage II: Forming: this is the first stage of industrial park development and affordable housing projects for workers, corresponding to the formation period of IP is below 10 years and the fill rate of IP is under $40 \%$;

- Stage III: Developing: corresponding to the formation period of IP is from 10 years and above, the fill rate of IP is higher than $40 \%$;

Accordingly, North Thang Long IP affordable housing is in Stage III and Phu Nghia IP is in Stage II.

Each stage should have specific regulations with regard to quality and quantity of the minimum infrastructure system, such as educational institution health facility, retail areas. Especially, it is crucial to have the provisions related to the small-scale retail areas to serve the daily lives of laborers.

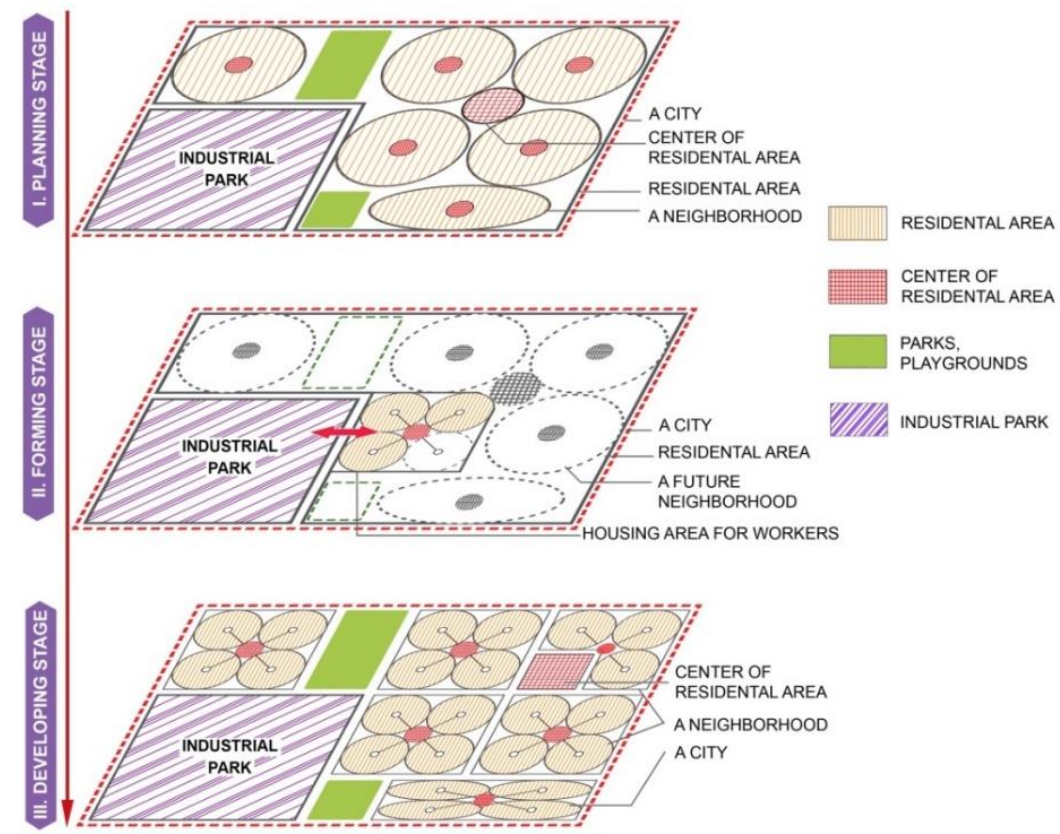

Fig. 2. Formation and development of affordable housing projects for workers 


\subsection{Small-scale retail areas should be added into the planning regulation of infrastructure system in affordable housing projects}

There is a fact that small-scale retail areas such as food stores, groceries, laundries are essential for laborers to meet their basic needs. However, the planning law does not have any regulation for them. In reality, many local people use the vacant and uncontrolled spaces for their private purpose, leads to lots of complicated social problems. As a result, it could be better for the government to issue regulations and standards in terms of using land for smallscale retail areas in affordable housing projects.

Small-scale retail areas are proposed to divide into 4 groups: Food and beverage stores; Groceries (household cleaning products, personal care); Entertainment stores (book store, internet shop, coffee shop); and other services (laundries, clothes shop, furniture shop). Based on the stage of developing affordable housing project, quantity and distance to each group will be determined in detail.

\subsection{Establishing a system of indicators to measure infrastructure quality and evaluating case studies}

Step 1: Proposing a system of indicators to measure infrastructure quality with component factors

To determine the quality of infrastructure system specifically, this paper proposes component factors. The table below shows the criterion of infrastructure system in the left column and each indicator has its component factors in the right column (See Table 1).

Table 1. A system of indicators to measure infrastructure quality.

\begin{tabular}{|c|c|}
\hline Indicator & Component factor \\
\hline \multicolumn{2}{|l|}{ 1. Technical infrastructure } \\
\hline \multirow{2}{*}{ 1.1 Transport network } & Completion \\
\hline & Specification \\
\hline \multirow[t]{5}{*}{1.2 Water supply } & Stability \\
\hline & Quality and reliability of water supply equipment \\
\hline & Percentage of household with water supply \\
\hline & Water supply specification for housing \\
\hline & Water supply specification for public \\
\hline \multirow[t]{2}{*}{ 1.3 Drainage system } & Stability \\
\hline & Drainage system specification \\
\hline \multirow[t]{5}{*}{ 1.4 Power supply } & Stability \\
\hline & Quality and reliability of power supply equipment \\
\hline & Specification of electrical substation \\
\hline & Power supply specification for housing \\
\hline & Power supply specification for public areas \\
\hline \multirow[t]{2}{*}{ 1.5 Waste collection } & Total area \\
\hline & Rate of waste collection \\
\hline \multicolumn{2}{|l|}{ 2. Social infrastructure } \\
\hline \multirow[t]{2}{*}{ 2.1 Educational institution } & Distance to kindergartens, primary schools \\
\hline & Location and total area \\
\hline \multirow[t]{3}{*}{2.2 Health facility } & Distance to drugstores, clinics \\
\hline & Distance to hospitals \\
\hline & Location and total area \\
\hline \multirow{3}{*}{ 2.3 Retail areas } & Distance to local markets \\
\hline & Distance to supermarkets, shopping malls \\
\hline & Location and total area \\
\hline 2.4. Cultural and sport centers & Distance to open spaces in residential area \\
\hline
\end{tabular}




\begin{tabular}{|l|l|}
\hline Indicator & Component factor \\
\hline \multicolumn{2}{|l|}{ Technical infrastructure } \\
& Distance to cultural and sport centers \\
\cline { 2 - 2 } 2.5 Administration office & Location and total area \\
\cline { 2 - 2 } & Distance to administration office \\
\hline \multirow{2}{*}{2.6 Parks, open spaces } & Location and distance \\
\cline { 2 - 2 } & Dotal area and landscape design \\
\hline $\begin{array}{l}\text { 2.7 Quantity of small-scale } \\
\text { retail areas }\end{array}$ & Food and beverage stores - Groceries \\
\cline { 2 - 2 } $\begin{array}{l}\text { 2.8 Distance to small-scale } \\
\text { retail areas }\end{array}$ & Entertainment stores - Other services \\
\cline { 2 - 2 } & Distance to Food and beverage stores - Groceries \\
\hline
\end{tabular}

Step 2: Determine weighting values and evaluated points of indicators

The survey was carried out on workers living in Thang Long IP affordable housing and Phu Nghia IP affordable housing. The importance of indicators was calculated and the result of processing data is weighting values (See Figure 3).

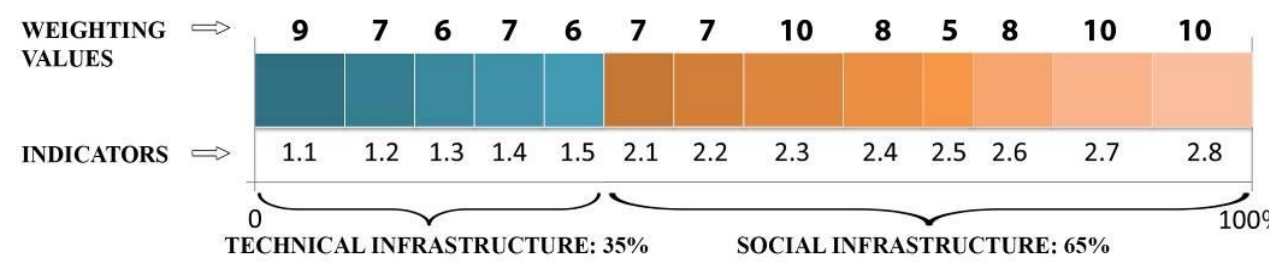

Fig. 3. Weighting values of indicators (Indicator legend: See Table 1).

While affordable housing project in North Thang Long IP was funded by the government, the investment budget of the affordable housing project in Phu Nghia IP is fully from enterprise's capital. As a result, the project in North Thang Long IP has fully-equipped social infrastructure system and the project in Phu Nghia IP has some public areas such as a restaurant, a playground and a local garden (See Figure 4).

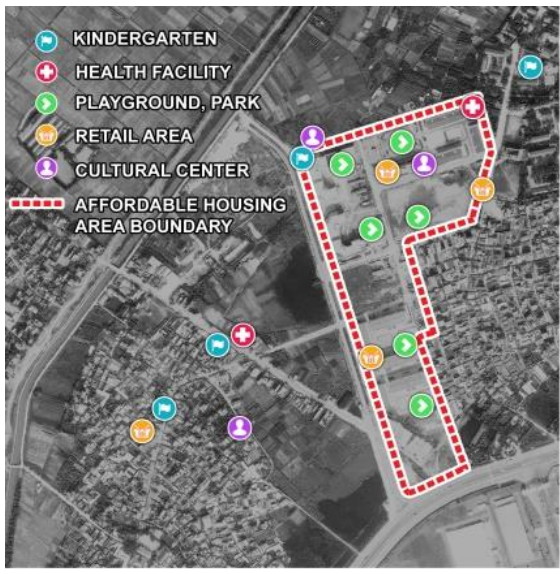

NORTH THANG LONG AFFORDABLE HOUSING PROJECT

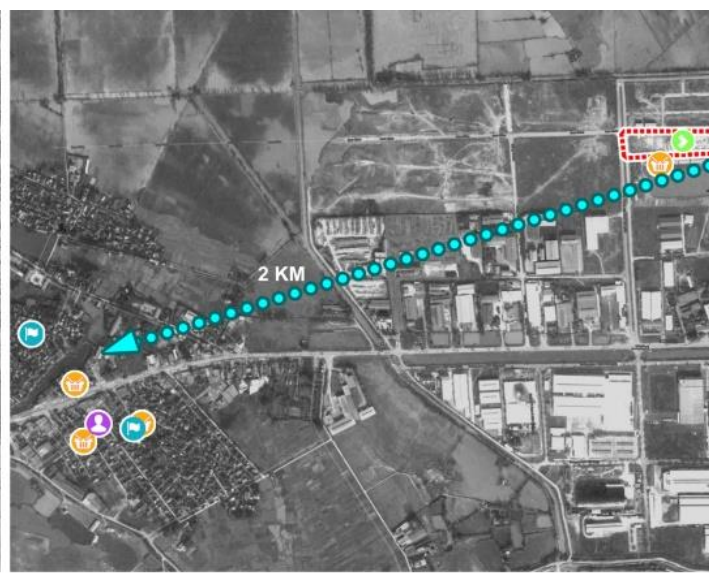

PHU NGHIA

AFFORDABLE HOUSING PROJECT

Fig. 4. Social infrastructure system in affordable housing projects.

Based on the survey, the evaluated points of indicators in the two affordable housing areas are represented below (See Figure 5). 


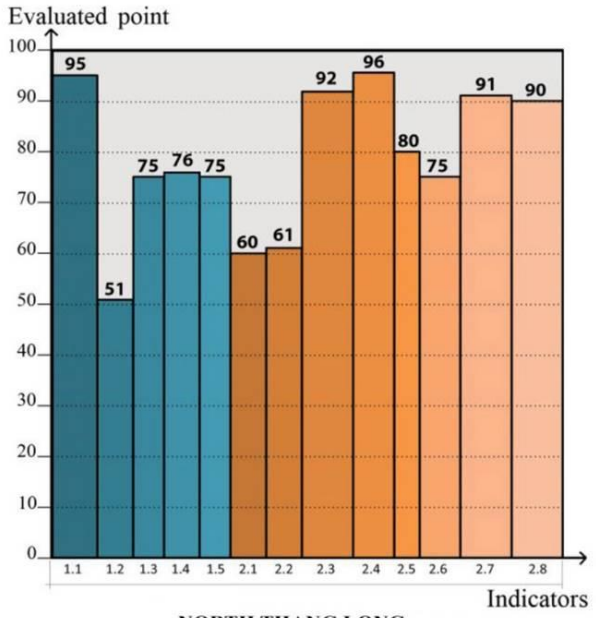

NORTH THANG LONG

AFFORDABLE HOUSING PROJECT

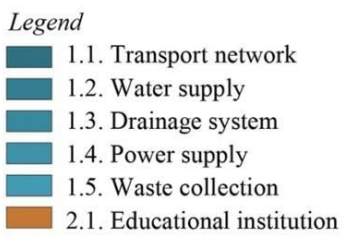

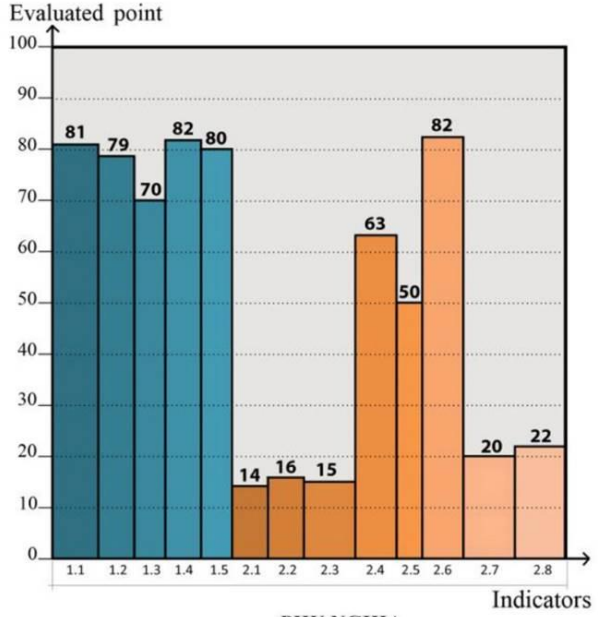

PHU NGHIA

AFFORDABLE HOUSING PROJECT

2.2. Health facility

2.3. Retail areas

2.4. Cultural and sport centers

2.5. Administration office

2.6. Parks, open spaces

2.7. Quantity of small-scale retail areas

2.8. Distance to Small-scale retail areas

Fig. 5. Comparing the two affordable housing projects for workers in terms of the quality of infrastructure system.

Step 3: Assessing quality of infrastructure system based on weighting values

By using formulas (01) and (02), the total point of infrastructure system in Thang Long IP affordable housing is 79.9 and in Phu Nghia IP affordable housing is 49.5.

Step 4: Determine level of infrastructure system quality

Based on formation time of affordable housing areas, infrastructure system quality is divided into 4 levels: Fail, Pass, Fair and Good (See Table 2).

Table 2. Levels of infrastructure system quality.

\begin{tabular}{|c|c|c|c|c|}
\hline Stage & \multicolumn{4}{|c|}{ Total point } \\
\hline Stage II (Forming stage) & $\leq 40$ & $40-50$ & $51-70$ & $\geq 71$ \\
\hline $\begin{array}{c}\text { Stage III (Developing } \\
\text { stage) }\end{array}$ & $\leq 70$ & $70-80$ & $81-90$ & $\geq 91$ \\
\hline Level & Fail & Pass & Fair & Good \\
\hline
\end{tabular}

The two surveyed projects have final scores and levels of infrastructure system quality as table below (See Table 3).

Table 3. Levels and final scores of two affordable housing projects for workers.

\begin{tabular}{|c|c|c|}
\hline \multirow{2}{*}{ Comparison } & \multicolumn{2}{|c|}{ Afforable housing project } \\
\cline { 2 - 3 } & North Thang Long IP & Phu Nghia IP \\
\hline Formation period of IP & 20 years & 9 years \\
\hline Fill rate of IP & $100 \%$ & $30 \%$ \\
\hline $\begin{array}{c}\text { Stage of affordable housing } \\
\text { project }\end{array}$ & III & II \\
\hline Total point & $\mathbf{7 9 . 9}$ & $\mathbf{4 9 . 5}$ \\
\hline Level & Pass & Pass \\
\hline
\end{tabular}


Thus, the final scores above reflected the reality in infrastructure system of the two projects. Infrastructure items in North Thang Long affordable housing project are more complete than in Phu Nghia project. However, the quality and services in North Thang Long project have decreased over the time. In Phu Nghia project, though people moved to this apartment 9 years ago, it has still lacked many essential facilities such as educational institution and health care center. If there is no plan to have more items, Phu Nghia project will cannot pass the lowest quality level in next few years.

\section{Discussion}

Construction of workers' housing projects is often stagnant. Most of industrial park developers and enterprises are not interested in developing this field. Some causes of this problem are difficulties in legal procedures, in accessing to land, in site clearance process and a lack of fund. While investment income is limited, the government has not had any incentive yet. Moreover, there are not any regulations in terms of construction schedule for infrastructure system in affordable housing projects. It leads to the lack of essential infrastructure items though people have moved to their apartments a few years ago.

The infrastructure system in workers' housing has not been paid enough attention. Although there are provisions in affordable housing planning and most of them are easier than in commercial residential planning, there are no specific regulations on the quantity and quality of necessary infrastructure items related to the developing stage of housing areas as well as industrial zones.

It is necessary to have some policy innovations. Based on the experience from developed countries, it cannot be denied that developing infrastructure system require large investment, but a long payback time. As the result, the government should play a leading role in the development of this field. It is crucial to have regulations and standards for the construction of workers' housing. Furthermore, the government should provide policies to encourage investment, such as simplifying construction procedures, create preferential loans, supporting enterprises in income tax, interest rate, and lending time for workers' housing projects.

In addition, the government should have some solutions in terms of investing. It is essential to establish the Workers' Housing Development Fund. Since then, employees and employers will contribute a part of their income or their regular profit to develop this fund. Besides, the resources can come from the government budget, non-governmental organizations, and donors. The fund should be managed by a state agency and that agency is responsible for raising capital, supporting companies in legal procedure, and researching strategies to develop workers' housing projects effectively. Moreover, the agency could be an operator or an investor of affordable housing projects for workers with full infrastructure system.

Another solution of increasing affordable housing is Build-Operate-Transfer method (BOT). Investors develop housing for laborers and they are permitted to invest in other projects outside IPs, for instance, commercial projects in city center. It could be an effective solution in the context of limited investment in affordable housing for workers.

\section{Conclusion}

Theoretically, the research shows that infrastructure system plays an important role in affordable housing planning for workers to ensure the quality of their lives. Housing for laborers has some different features from residential areas in cities because it depends on the formation period and fill rate of IPs, so that the regulations of affordable housing planning should be adapted to real situation of each IP, especially in social infrastructure system. 
In reality, it seems impossible for the government to invest all infrastructure system and affordable housing for employees. However, the government should issue regulations to encourage investment from private businesses. With current policies, this is an investment field with low economic efficiency and risk. Hence, it is crucial for the government to cooperate private enterprises. Developing the infrastructure system in affordable housing projects should be divided into a number of stages and each stage should have the minimum requirement in terms of quality and quantity for each category. In this research, the number of respondents is limited and the survey is carried out just in Hanoi. As a result, the quality assessment method should have distinct characteristics to adapt to different areas and should be updated periodically.

\section{References}

1. Vietnamese Construction Law No.50/2014/QH13 (2014)

2. A. Moskalyk, Role of Public-Private Partnerships in Funding Social Housing in Canada, CPRN Research Report (2008)

3. T. L. Duong, T. D. Nguyen, Q. D. Tran, V. T. Bui, Solutions to developing state housing for low income people in the cities of Vietnam, Student's scientific research contest, NUCE (2010)

4. H. H. Nguyen, Improving the efficiency of land use for affordable housing project for worker in Thang Long IP, Kim Chung Ward, Dong Anh District, Hanoi, Master Thesis of Land Administration (VNU University of Science, 2011)

5. L.S. Arifin, Housing provision for factory workers (Petra Christian University, Surabaya, Indonesia, 2001)

6. Ai Tee Goh, Yahaya Ahmad, Public low-cost housing in Malaysia: case studies on PPR low-cost plats in Kuala Lumpur (University of Malaya, 2011)

7. S. Shuid, Low medium cost housing in Malaysia: Issues and challenges (International Islamic University Malaysia, Malaysia, 2004)

8. Law of Malaysia Act 1990, Workers' Minimum Standards of Housing and Amenities (The commissioner of Law revision, Malaysia, 2006)

9. Seventh Malaysia Plan, Chapter 18-Housing and other social services (1996-2000)

10. Y. K. Sheng, A. Rahman, Housing Women Factory Workers in the Northern Corridor of the Bangkok Metropolitan (UBC Press, Vancouver, 1995)

11. Vietnamese Ministry of Planning and Investment, JICA, Seminar on Results of the study for improvement of living conditions for workers around industrial zones in the Socialist Republic of Vietnam (2016)

12. The Institute of Workers, Vietnam General Confederation of Labor, Survey on workers' lives in 10 provinces and cities (2015)

13. National strategy on Housing development through 2020 with a vision toward 2030 , Decision No. 2127/QD-TTg (Vietnam, 2011)

14. Vietnamese Law on Housing No. 65/2014/QH13 (2014)

15. T. P. Ngo, Evaluating indicators and method to measure quality of multi-storey buildings, ISBN: RD-05-02 (2004)

16. L. H. Le, A. D. Ta, H. Q. Dang, Procedia Engineering 142, 116-123 (2016) 